\title{
Antimicrobial and Antioxidant activity of Fermented Bamboo Shoot Dendrocalamus hamiltonii
}

\author{
Sonia Angeline $\mathbf{M}^{1 *}$, Challaraj Emmanuel E S², Ramtovan Nonglait ${ }^{2}$, Balahuling Suting ${ }^{2}$ \\ Department of Life Sciences, Kristu Jayanti College (Autonomous), Bengaluru \\ *Corresponding author: sonia.m@kristujayanti.com
}

\begin{abstract}
Bamboo is a perennial, woody grass, belonging to the Poaceae Family. Different bamboo species have been found to have therapeutic applications and studies have shown that bamboo have medicinal uses such as anti-cancer activity, anti-oxidant activity, antimicrobial activity, anti-diabetic activity, anti-inflammatory activity, anti-fertility activity and antihypertensive. In this study, fermented bamboo was used for extraction of phytochemicals and analysis of their antimicrobial and antioxidant activity. The extract was characterized by FTIR. The acetone and methanol extracted yield of $25.78 \%$ and $31.08 \%$ respectively. The scavenging activity with ascorbic acid for methanol showed $17.3 \%$ for $10 \mathrm{mg} / \mathrm{ml}$ whereas no activity for acetone. But extract showed antimicrobial and antioxidant activity.
\end{abstract}

Keywords Bamboo, Staphylococcus aureus, Escherichia coli, Pseudomonas aeruginosa Fusarium sp., Phytochemicals

\section{Introduction}

Bamboo is a fast-growing species. This plant is a giant, woody grass consisting of two segments- rhizomes and culms. The rhizome constitutes the underground part of the plant, which emerges from the ground to form individual stems or culms. The culms grow into full height and diameter during the monsoon season of 4-6 months; however, maturity period may range from 2-6 years. Bamboo shoots are the culms that usually tapers at one end and grows extraordinarily. They are usually harvested at the point of attachment to the rhizome. The shoots have been used as both food and medicine in Southeast Asian countries. They are low in fats and sugars, however, are rich in proteins, carbohydrates, minerals, and dietary fibres (1). Previous studies reveal the contents of nutrients such as carbohydrates $(5.70 \%)$, protein $(3.9 \%)$, minerals $(1.1 \%)$, and moisture $(88.8 \%)$ along with low concentration of cholesterol and saturated fats (total fats $0.5 \%$ ). Bamboo also contains vitamin $E$ ( $a$ tocopherol), Vitamins $\mathrm{C}, \mathrm{B} 6$, thiamine, riboflavin, niacin, and dietary fibres. It has also been reported that bamboo shoot contains over 10 mineral elements such as $\mathrm{Cr}$, $\mathrm{Zn}, \mathrm{Mn}, \mathrm{Mg}, \mathrm{Co}, \mathrm{Cu}$, lysine, germaclinium and many nutritious and active minerals (2). It has been found that the protein content of the fermented bamboo shoot is $8.5 \%$. This percentage of protein is more than that of the unfermented or fresh bamboo shoots. It is now being named as the 'timber of $21^{\text {st }}$ century', 'green gold', or 'wood and food for $21^{\text {st }}$ century' and poised to replace wood for almost all practical purposes (3).

Bamboo shoots are usually harvested when they are 2 weeks old or 1-foot tall for its use as food. Only young and tender bamboo shoots are used. The fresh young shoots are usually creamy yellow in colour and has a strong aroma and sour tastes. The pungent taste of the shoots is mainly due to the presence of homogentisic acid (4). However, the tenderness, taste and aroma are lost once attained maturity. The predominant lactic acid bacteria found in the fermented bamboo shoot of Meghalaya are Lactobacillus brevis, I. curvatus, Leuconostoc mesenteroides, $L$. fallaz, $L$. lactis, L. citreus (5). Plant parts such as leaves, roots, rhizomes, stems, barks, flowers, fruits, grains or seeds are employed in the control or treatment of disease conditions due to the presence of medically active chemicals. These bioactive compounds are often referred to as phytochemicals or phytoconstituents that are responsible for the plants to defend against microbial infections. The classes of phytochemicals are alkaloids, glycosides, flavonoids, phenolics, saponins, tannins, terpenes, anthraquinones, essential oils, and steroids (6). The evaluation of phytochemicals both in quality and quantity leading to drug discovery are referred to as natural product screening. Various environmental factors affect the growth of the plants that in turn affects the plant's ingredients. Phytochemicals inhibit growth of microorganisms, interfere in their metabolic activities, changes gene expression and signal transductions. They may also interfere with the phospholipid bilayer of the cell membrane that results in the loss of cellular components due to the increase in the permeability, damage of the enzymes involving in the cellular energy production and inactivation of genetic material (6). Due to oxidative stress, free radicals, also known as reactive oxygen species are generated during metabolism (7). Due to the instability and reactive property of free radicals, they tend to cause many physiological and pathological effects such as inflammation, aging, mutagenicity, carcinogenicity, cardiovascular diseases, atherosclerosis, diabetes, asthma, hepatitis and arthritis $(7,8)$. The damage is caused by reactive oxygen species (ROS) and reactive nitrogen species (RNS). Antioxidants help in delaying the reaction of free radical oxygen 
species (7). They scavenge or neutralize the radicals before the cells are attacked which causes damage to lipids, carbohydrates, enzymes, carbohydrates DNA. Synthetic antioxidants such as butylated hydroxytoluene (BHT) and butylated hydroxyanisole (BHA) are toxic for humans; hence, the need to use natural antioxidants is important.

The use of extracts of plants that contain phytochemicals are of great therapeutic uses. Some phytochemicals such as phenolic acids help the reduction of the adherence of organisms to the lining of bladder and teeth. This ultimately lowers urinary tract infections (UTI) and dental infections respectively (6). Therefore, phytochemicals may have applications in bioactive nutraceuticals, bio- pharmaceuticals and food additives (9). Various studies have been carried out on the bamboo species. Scientists studied the germination of seed and growth of seedlings of Dendrocalamus hamiltonii. Invitro studies on Dendrocalamus hamiltonii has been carried out where its micropropagation is done with the help of growth regulators such as auxins and cytokinins (10). The presence of the different nutrients in the fresh/ unfermented bamboo shoot of edible Dendrocalamus hamiltonii like the moisture, protein, fats, ash, fibres and total carbohydrates have been found. Similarly, nutrient composition and organoleptic evaluation have also been carried out for its edible products such as chutney, candy, chukh, nuggets and crackers (11). The loss of moisture and weight loss have been detected in Dendrocalamus hamiltonii affected by the fungus Fusarium proriferatum and Schizophyllum commune due to maturity (12).

Chavhan et al., (2015) (13) mentioned that the incorporation of fermented bamboo shoot on pork pickle in the form of paste, powder and extract have both antibacterial and antilipolytic effects. Hence, there is a potential of replacing the chemical preservatives with the fermented bamboo shoot. Similarly, fermented bamboo shoot has also been found to have a positive effect on the shelf-life and quality of the nuggets prepared from desi spent hen. The nuggets treated with fermented bamboo shoot have found to have a superior quality than the untreated ones (14). In this present study, phytochemical analysis, antimicrobial property of fermented Bambusa balcooa shoots collected in Manipur was analysed using various techniques. FTIR was used for characterization. The main aim of the study is the antimicrobial and antioxidant activities of fermented Dendrocalamus hamiltonii.

\section{Materials and Method}

\section{Collection of samples}

The sample was collected from the market (lewduh) of Shillong, Meghalaya, India.

\section{Extraction of phytochemicals}

The fermented bamboo shoots were washed with double distilled water and then diced into small pieces.
The diced fermented bamboo shoots were dried in hot air oven at $50^{\circ} \mathrm{C}$ for about $10-16$ hours. Two different solvents such as methanol and acetone were used for the extraction process. $50 \mathrm{~g}$ of dried fermented bamboo shoots were taken and soaked overnight in $300 \mathrm{ml}$ of each solvent in Soxhlet apparatus. After extraction of 15 cycles, the crude liquids were placed in water bath at $60^{\circ} \mathrm{C}$ to remove excess solvent. The weight of the sample before and after the extraction was noted.

The extraction yield of the extracts using methanol and acetone solvents is calculated as:

Percentage of extraction yield $(w / w)=\left(m_{1}-m_{2} / m_{1}\right) \times 100$ ' $m_{1}$ ' is the mass of the sample before extraction ' $\mathrm{m}_{2}$ ' is the mass of the sample after extraction

\section{Phytochemical Analysis}

\section{Identification of Constituents by different Qualitative Test}

The extracts were subjected to different qualitative test for the detection of different phytochemicals. The standard method was employed for the detection of alkaloids, terpenoids, saponins, phenols, tannins, oils and resins, steroids, carbohydrates, flavonoids and proteins.

\section{Test for alkaloids}

Extracts were dissolved in dilute hydrochloric acid and then filtered. The filtrate was treated with Mayer's reagent (Potassium Mercuric lodide) (15).

\section{Test for terpenoids}

$2 \mathrm{ml}$ of chloroform was added to the extracts, then followed by addition of $3 \mathrm{ml}$ concentrated sulphuric acid.

\section{Test for saponins}

$0.5 \mathrm{~g}$ of extract was shaken with $2 \mathrm{ml}$ of water(15).

\section{Test for phenols}

The extracts were treated with 3-4 drops of ferric chloride solution.

\section{Test for tannins}

The extracts were dissolved in $45 \%$ ethanol. Then boiled for 5 minutes and 15\% ferric chloride is added to each extract (16).

\section{Test for oils and resins}

The extract was applied on a Whatman filter paper for detection oils and resins.

\section{Test for steroids}

$2 \mathrm{ml}$ of acetic anhydride was added to the extract and to this $2 \mathrm{ml}$ of concentrated sulphuric acid was added.

\section{Test for carbohydrates}


The extract was taken in a test tube and Fehling's solution $A$ and $B$ is added and kept in boiling water bath.

\section{Test for flavonoids}

Extracts were treated with $5 \%$ ammonia. To this, 1 $\mathrm{ml}$ of concentrated sulphuric acid was added.

\section{Test for proteins (Ninhydrin test)}

To the extract, $0.25 \mathrm{w} / \mathrm{v}$ Ninhydrin reagent was added and boiled for few minutes for detection of amino acids $^{15}$.

\section{Fourier Transform- Infrared Spectroscopy (FT-IR)}

FT-IR was performed to identify the functional group present in the sample. Powdered sample was used for the analysis. The scan was performed from $400-4000$ $\mathrm{cm}^{-1}$ range in Perkin model.

\section{Antioxidant Activity - Hydrogen Peroxide Scavenging Capacity}

The hydrogen scavenging capacity of the fermented bamboo shoot is determined according to the method of Serhat et al., 2012 (17). In this method, 40 mM hydrogen peroxide solution was prepared in phosphate buffer $(\mathrm{pH} 7.4), 10 \mathrm{mg} / \mathrm{ml}$ and $20 \mathrm{mg} / \mathrm{ml}$ of plant extract was added to $0.6 \mathrm{ml}$ of hydrogen peroxide into respective test tubes and then incubated for 10 minutes. Absorbance of hydrogen scavenging capacity is measured using spectrophotometer at $230 \mathrm{~nm}$. Phosphate buffer without hydrogen peroxide serves as the blank and the extract in phosphate buffer without hydrogen peroxide serves as control. Ascorbic acid is used as standard. The percentage of hydrogen peroxide scavenged is calculated by the following formula:

\section{$\%$ Scavenged hydrogen peroxide $=[(A c-A s) / A c]$ $\times 100$}

Where, 'Ac' is the absorbance of control and 'As' is the absorbance of sample.

\section{Antibacterial activity}

Antibacterial activity was determined by AgarWell Diffusion Method (18). Different concentration of the extracts $10,20,30,40,50 \mathrm{mg} / \mathrm{ml}$ respectively were prepared by dissolving the extracts in dimethyl sulfoxide (DMSO). $0.1 \mathrm{ml}$ of the test organism was inoculated onto Muller-Hinton Agar using spread plate technique. Different concentration of the extract was introduced into respective wells. The plates were then incubated at $37^{\circ} \mathrm{C}$ for 24 hours. Gentamycin and DMSO are used as positive and negative control respectively. After incubation, the zone of inhibition was measured. Each test is done in triplicates and the mean diameter of inhibition zone was observed and recorded.

\section{Antifungal effect}

Evaluation of the antifungal effect is determined by the Food Poisoned Method ${ }^{18}$. Different concentration of the extracts $10,20,30,40,50 \mathrm{mg} / \mathrm{ml}$ respectively of the extracts are inoculated into sterile petri plates. SDA medium $\left(45^{\circ} \mathrm{C}\right)$ was poured into the plates and mixed well. The mycelial disc of the test organism was inoculated into the centre of the agar plates. Plates without the extract serve as control. The plates were then incubated at room temperature for 5 days. The diameter of the fungal growth of both the test and control were measured. Each test is done in triplicates and the mean diameter of the mycelial growth is observed, measured and recorded. The antifungal effect is estimated by the following formula:

\section{Antifungal Activity $(\%)=\left(D_{c}-D_{s} / D_{\partial}\right) \times 100$}

Where ' $D_{c}$ ' is the diameter of fungal growth in control plate (without extract) and ' $D_{s}$ ' is the diameter of fungal growth in the plate with extracts.

\section{RESULTS AND DISCUSSION}

\section{Extraction Yield}

The fermented bamboo and diced bamboo before and after dried are shown in Figure 1 and 2 respectively. The extraction yield was calculated by measuring the weight of the sample before extraction and dry weight after extraction (Table 1). In most of the studies, methanol
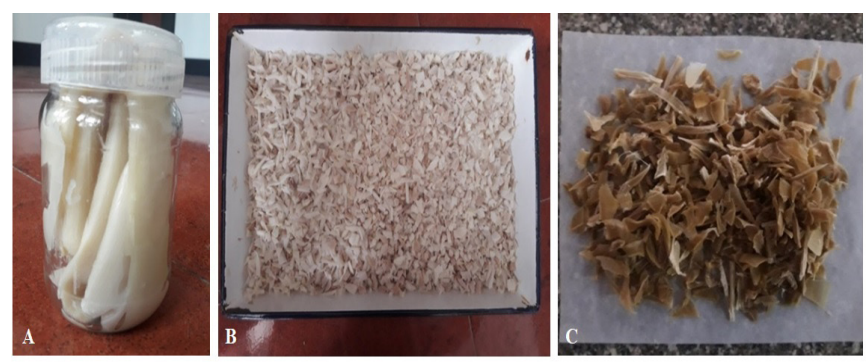

Fig. 1: (A) Fermented Bamboo Shoo Diced (B) Fresh Fermented Bamboo Shoot (C) Dried Fermented Bamboo Shoot

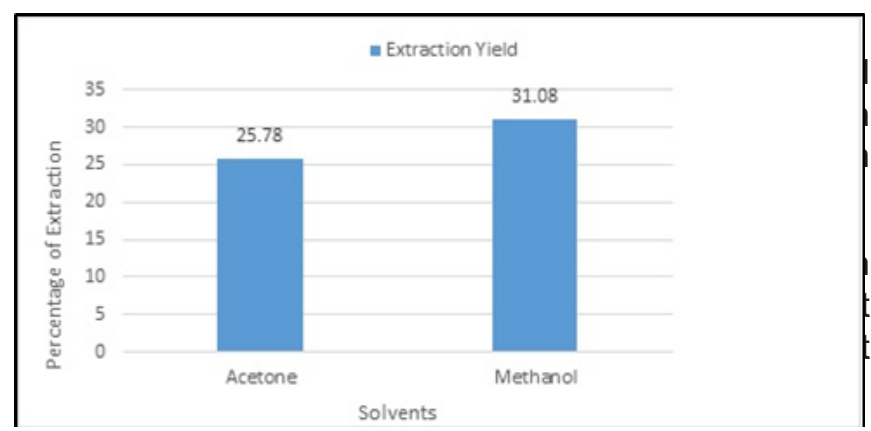

Fig. 2. Extraction yield of methanol and acetone extracts of fermented shoot of Dendrocalamus hamiltonii

\section{Phytochemical Analysis}

Identification of the phytochemicals present in fermented bamboo shoot is done by different qualitative tests such as Mayer's tests for alkaloids, Salkowski's test for terpenoids, foam test for saponins, ferric chloride test for phenols, Fehling' test for carbohydrates, Ninhydrin 
Table 1. Extraction Yield of Extracts of Fermented Dendrocalamus hamiltonii

\begin{tabular}{|c|c|c|c|}
\hline Solvents & $\begin{array}{c}\text { Weight of the } \\
\text { sample before } \\
\text { extraction(g) }\end{array}$ & $\begin{array}{c}\text { Weight of } \\
\text { the sample } \\
\text { after ex- } \\
\text { traction(g) }\end{array}$ & $\begin{array}{c}\text { Extraction } \\
\text { yield (\%) }\end{array}$ \\
\hline Acetone & 50 & 37.11 & 25.78 \\
\hline Methanol & 50 & 34.46 & 31.08 \\
\hline
\end{tabular}

test for proteins, alkaline reagent test for flavonoids and test for tannins, oils \& resins, steroids (Table 2 ). In the qualitative test, the phytochemicals present in the acetone extract are alkaloids, terpenoids, tannins, oils and resins, flavonoids and proteins. However, in the case of methanol extract, phytochemicals present are alkaloids, saponins, tannins, oils \& resins, flavonoids and proteins.

\section{Test for Alkaloid (Mayer's Test)}

After addition of Mayer's reagent to the filtrate, formation of yellow colour precipitate was observed on both methanol and acetone extract which indicates the presence of alkaloids.

\section{Test for Terpenoids (Salkowski Test)}

Table 2: Results of Qualitative Analysis of Phytochemicals

\begin{tabular}{|c|c|c|c|}
\hline SI. No. & Name of the Test & $\begin{array}{c}\text { Acetone } \\
\text { Extract }\end{array}$ & $\begin{array}{c}\text { Methanol } \\
\text { Extract }\end{array}$ \\
\hline 1 & $\begin{array}{c}\text { Alkaloid Test } \\
\text { (Mayer's Test) }\end{array}$ & + & + \\
\hline 2 & $\begin{array}{c}\text { Test for Terpe- } \\
\text { noids }\end{array}$ & + & - \\
\hline 3 & $\begin{array}{c}\text { Test for Saponins } \\
\text { (Foam Test) }\end{array}$ & - & + \\
\hline 4 & $\begin{array}{c}\text { Test for Phenols } \\
\text { Test for Tannins }\end{array}$ & + & - \\
\hline 5 & Resins & + & + \\
\hline 6 & Test for Oils \& & + & + \\
\hline 7 & $\begin{array}{c}\text { Test for Steroids } \\
\text { drates }\end{array}$ & - & - \\
\hline 10 & $\begin{array}{c}\text { Test for Proteins } \\
\text { Test for Flavonoids }\end{array}$ & + & + \\
\hline & + & + \\
\hline
\end{tabular}

After addition of chloroform and concentrated sulphuric acid to the extract, a reddish-brown colouration was observed in acetone extract but absent in methanol extract. This indicates that terpenoids is present in acetone extract while absent in methanol extract.

\section{Test for Saponins (Foam Test)}

After the extract is shaken with water, foam that persist for 10 minutes was observed in methanol extract but not in acetone extract. This indicates that saponins is present only in methanol extract.

\section{Test for Phenol (Ferric Chloride test)}

After the extract is treated with ferric chloride, the formation of bluish black was not observed in both methanol and acetone extract, thus indicating the absence of phenol in both the extract.

\section{Test for Tannins}

After the extract is dissolved in $45 \%$ ethanol, boiled for 5 minutes and followed by addition of ferric chloride, appearance of greenish colour was observed in both methanol and acetone extract. This indicates that tannins are present in both extracts.

\section{Test for Oils and Resins}

After the extract is applied to the Whatman paper, the transparent appearance of the paper was observed in both the methanol and acetone extracts. This indicates the presence of oils and resins in both the extracts.

\section{Test for Steroids}

Table 3. Antimicrobial Screening of acetone extracts of Fermented Bamboo Shoot Dendrocalamus hamiltonii

\begin{tabular}{|c|c|c|c|}
\hline $\begin{array}{c}\text { Concentration of } \\
\text { Acetone Extract } \\
(\mathrm{mg} / \mathrm{ml})\end{array}$ & $\begin{array}{c}\text { Zone of Inhibition(mm) } \\
\text { aureus }\end{array}$ & $\begin{array}{c}\text { Sseudomonas } \\
\text { aeruginosa }\end{array}$ & $\begin{array}{c}\text { Escherichia } \\
\text { coli }\end{array}$ \\
\hline 10 & $14 \pm 1.73$ & $11.6 \pm 0.57$ & $13 \pm 0$ \\
\hline 20 & $14.3 \pm 2.31$ & $12.6 \pm 0.57$ & $19.6 \pm 0.57$ \\
\hline 30 & $17.3 \pm 1.53$ & $15.6 \pm 0.57$ & $23.6 \pm 1.15$ \\
\hline 40 & $20.3 \pm 3.21$ & $16 \pm 1$ & $25.6 \pm 2.08$ \\
\hline 50 & $22.3 \pm 2.52$ & $17.3 \pm 0.57$ & $25.6 \pm 1.15$ \\
\hline Gentamycin & $36.7 \pm 2.8$ & $33.33 \pm 2.8$ & $40 \pm 0$ \\
\hline DMSO & 0 & 0 & 0 \\
\hline
\end{tabular}

After addition of acetic anhydride and concentrated sulphuric acid, the colour change from violet to blue or green was not observed on methanol and acetone extract, thus indicating the absence of steroids in both the extracts.

\section{Test for Carbohydrate (Fehling `s Test)}

After addition of Fehling's solution to the extracts 

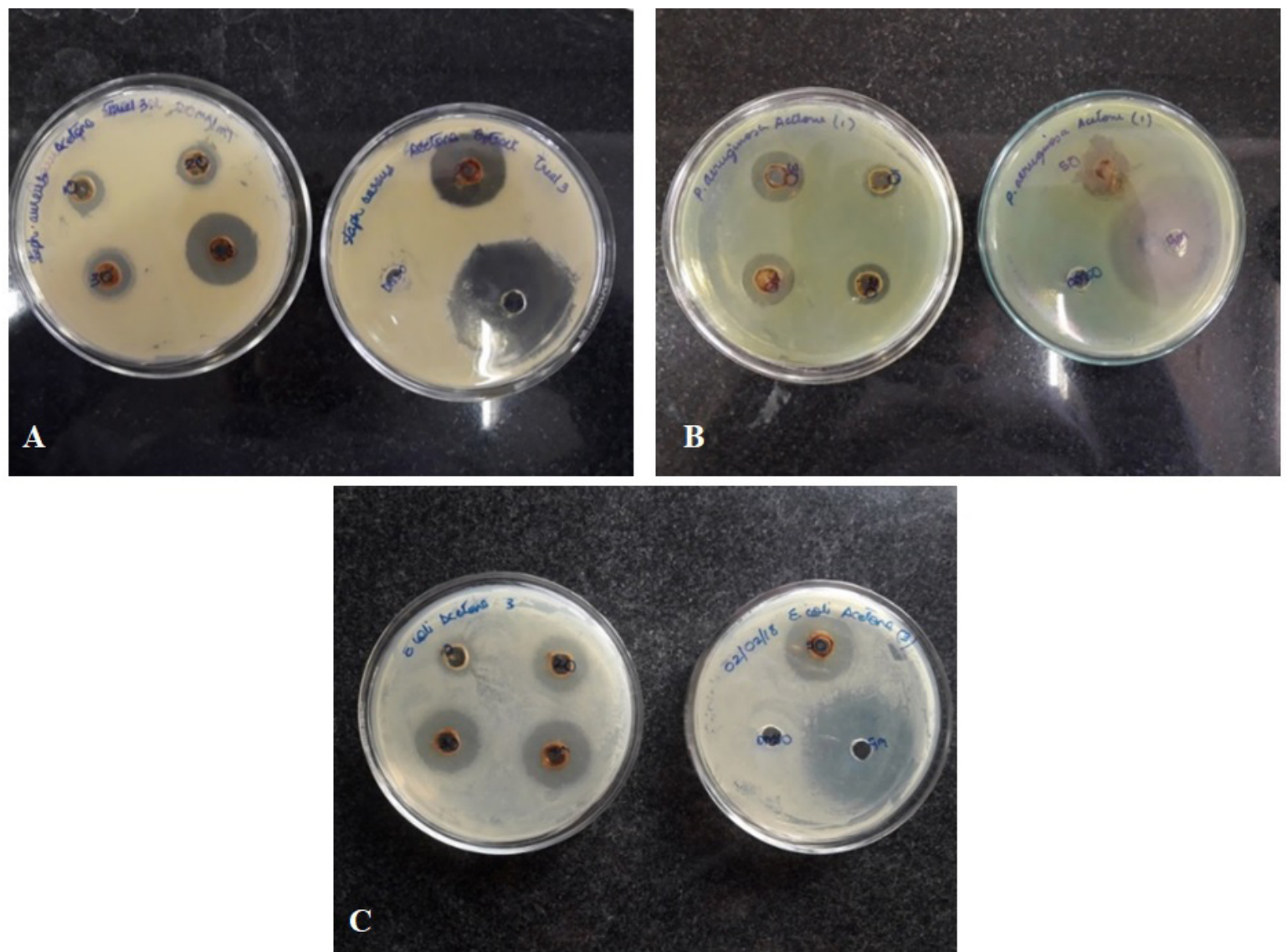

Fig. 3: Bacterial Growth in MHA medium containing Acetone Extract of Fermented Bamboo Shoot using Agarwell Diffusion Technique. (A) Staphylococcus aureus (B) Pseudomonas aureus (C) Escherichia coli

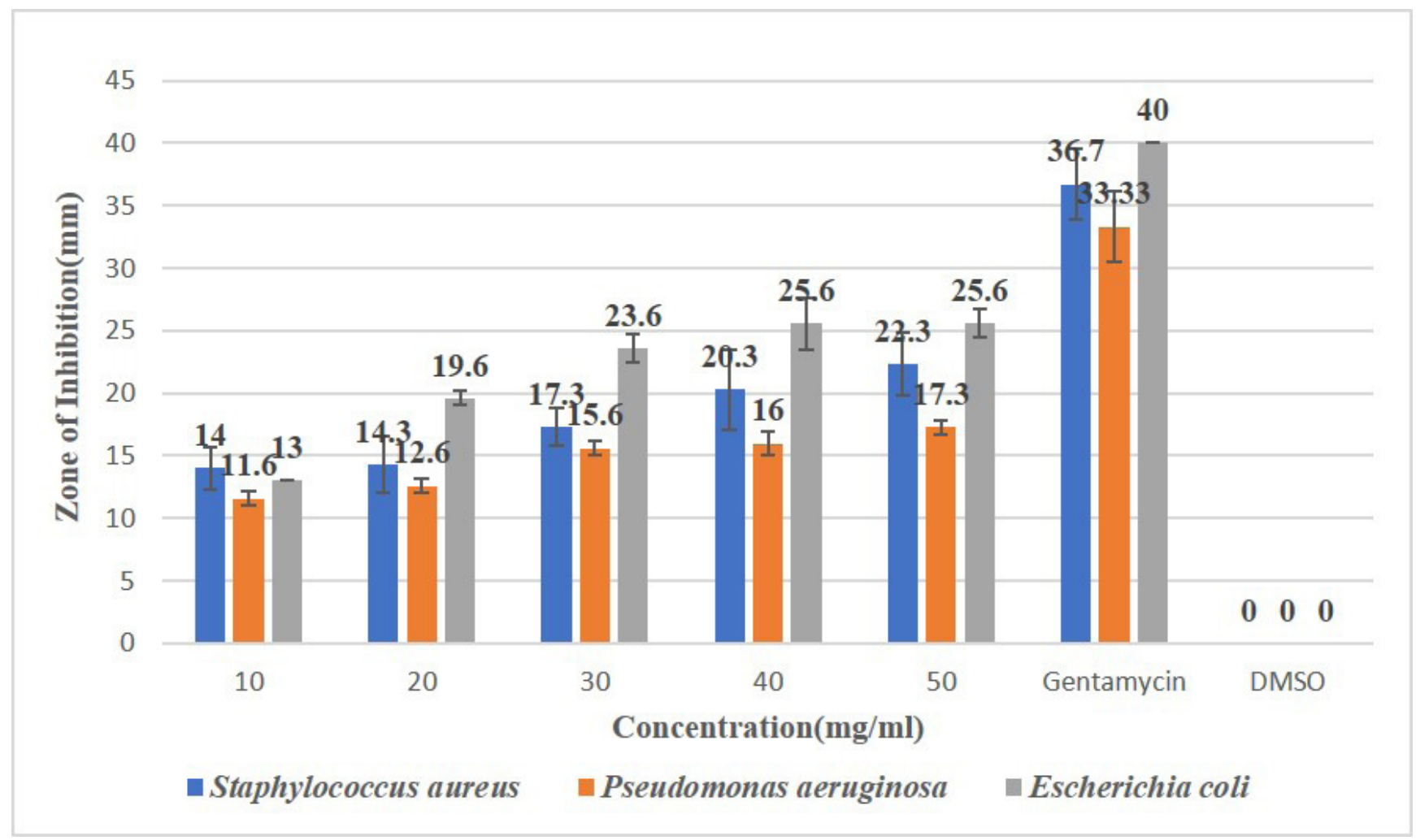

Fig. 4. Antibacterial Activity of Acetone Extracts of Fermented Bamboo Shoot Dendrocalamus hamiltonii 

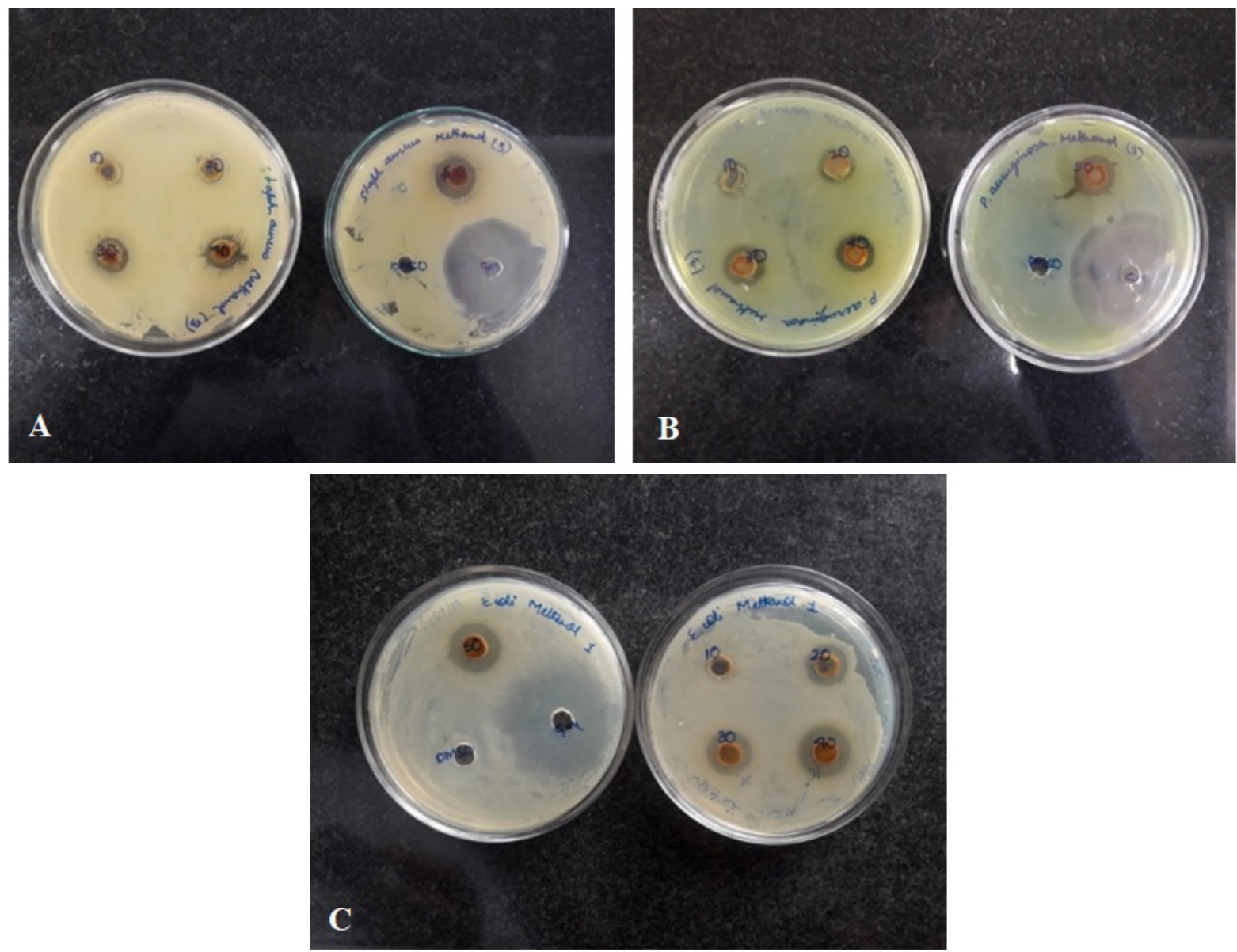

Fig. 5: Bacterial Growth in MHA medium containing Methanol Extract of Fermented Bamboo Shoot using Agar-well Diffusion Technique. (A) Staphylococcus aureus (B) Pseudomonas aureus (C) Escherichia coli

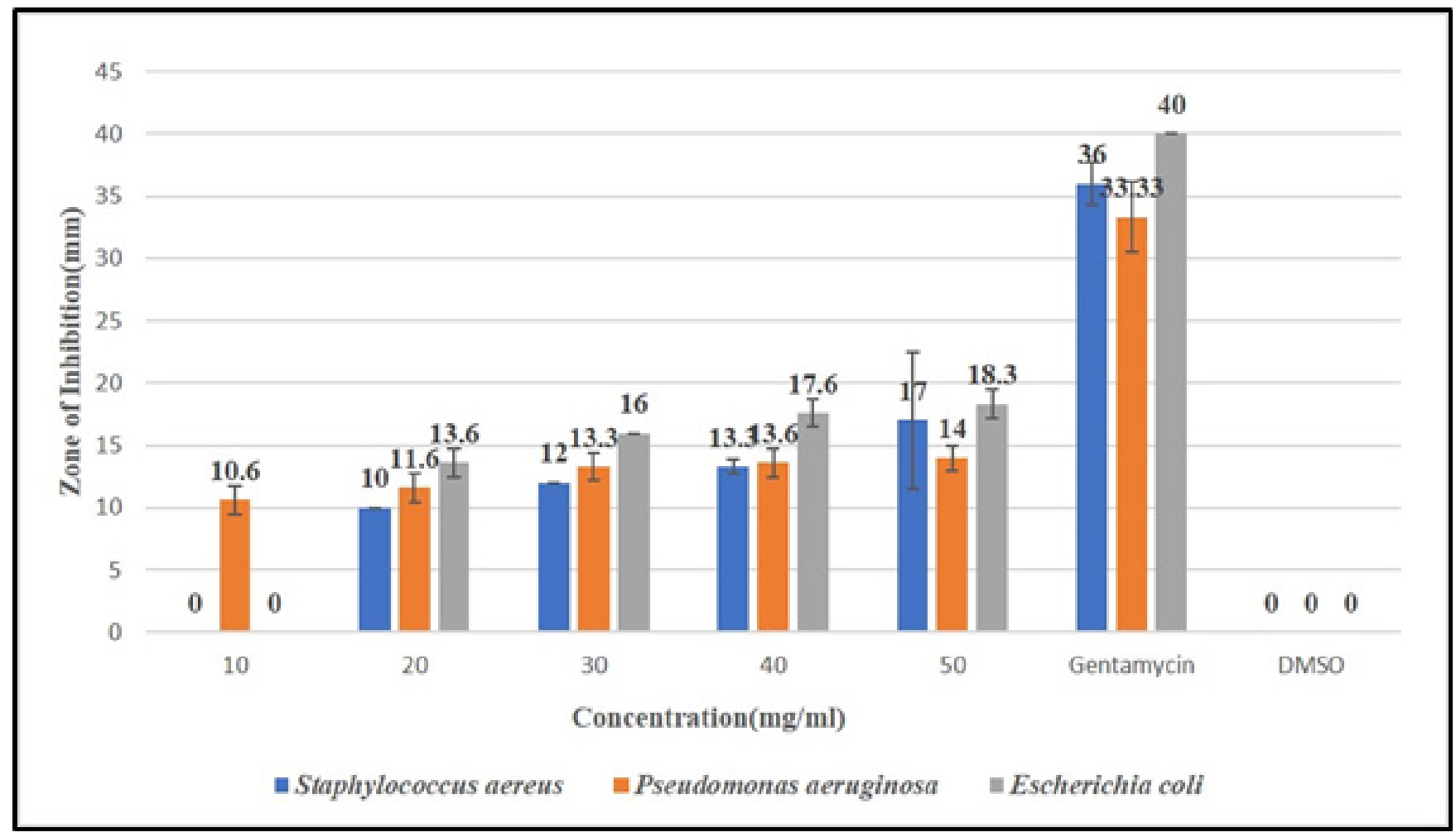

Fig 6. Antibacterial Activity of Methanol Extracts of Fermented Bamboo Shoot Dendrocalamus hamiltonii 
Table 4. Antimicrobial Screening of methanol extracts of fermented bamboo shoot (Dendrocalamus hamiltonii)

\begin{tabular}{|c|c|c|c|}
\hline \multirow{2}{*}{$\begin{array}{l}\text { Concentration of } \\
\text { Methanol Extract } \\
\qquad(\mathrm{mg} / \mathrm{ml})\end{array}$} & \multicolumn{3}{|c|}{ Zone of Inhibition(mm) } \\
\hline & $\begin{array}{c}\text { Staphylococcus } \\
\text { aureus }\end{array}$ & $\begin{array}{c}\text { Pseudomonas } \\
\text { aeruginosa }\end{array}$ & Escherichia coli \\
\hline 10 & 0 & $10.6 \pm 1.15$ & 0 \\
\hline 20 & $10 \pm 0$ & $11.6 \pm 1.15$ & $13.6 \pm 1.15$ \\
\hline 30 & $12 \pm 0$ & $13.3 \pm 1.15$ & $16 \pm 0$ \\
\hline 40 & $13.3 \pm 0.57$ & $13.6 \pm 1.15$ & $17.6 \pm 1.15$ \\
\hline 50 & $17 \pm 5.51$ & $14 \pm 1$ & $018.3 \pm 1.15$ \\
\hline Gentamycin & $36 \pm 1.73$ & $33.33 \pm 2.8$ & $40 \pm 0$ \\
\hline DMSO & 0 & 0 & 0 \\
\hline
\end{tabular}

and boiled in water bath, the formation of reddishbrown colour was not observed in both the extracts thus

Table 5. Antifungal activity of the Acetone Extract of Fermented Bamboo Shoot on Fusarium sp.

\begin{tabular}{|c|c|}
\hline $\begin{array}{c}\text { Concentration of Acetone } \\
\text { Extract }(\mathrm{mg} / \mathrm{ml})\end{array}$ & $\begin{array}{c}\text { Average Mycelia } \\
\text { Growth }(\mathrm{mm})\end{array}$ \\
\hline 10 & $56.6 \pm 3.5$ \\
\hline 20 & $45.0 \pm 0$ \\
\hline 30 & $45.0 \pm 0$ \\
\hline 40 & $42.0 \pm 0$ \\
\hline 50 & $41.0 \pm 0$ \\
\hline Control & 67.5 \\
\hline
\end{tabular}

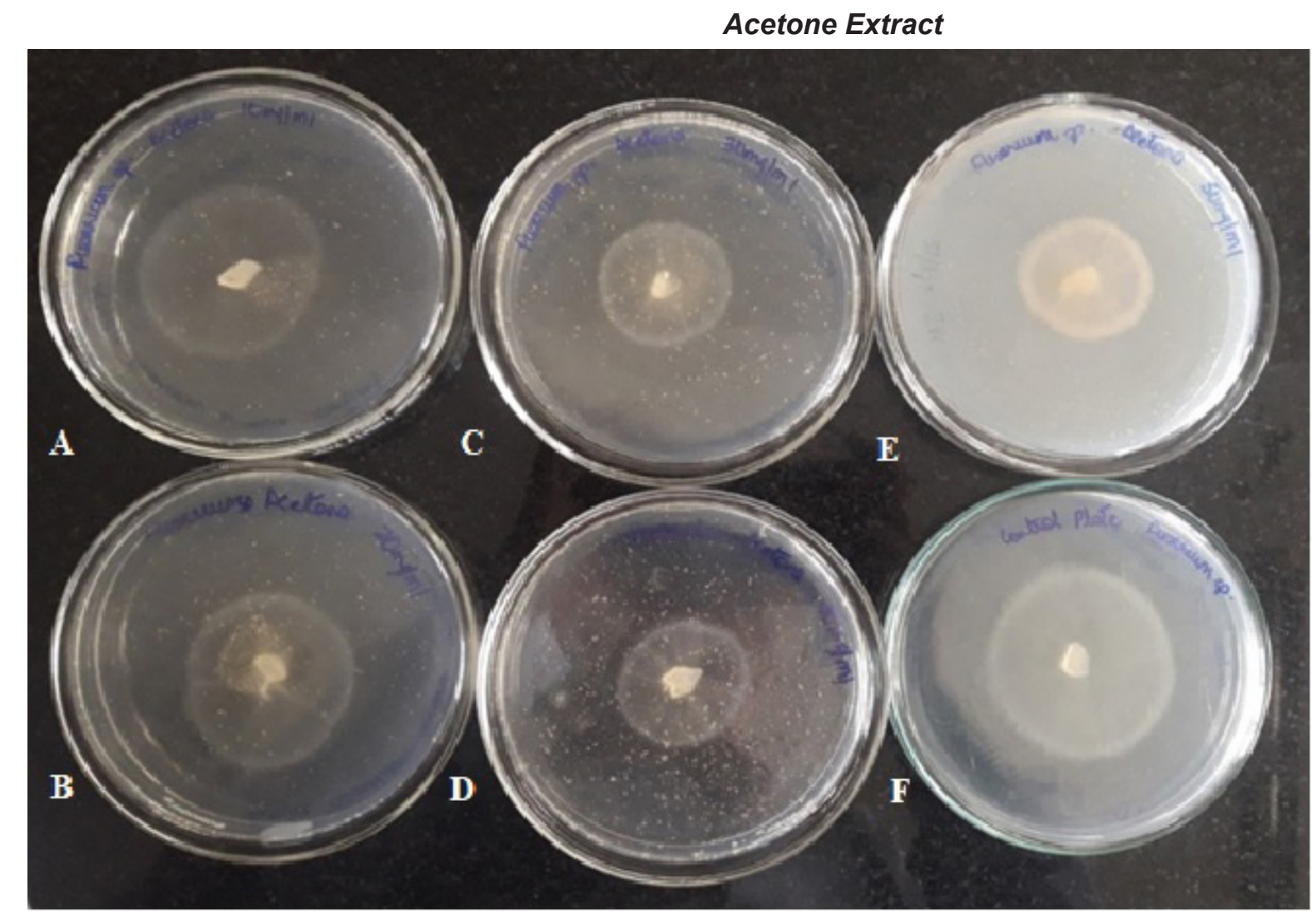

Fig. 7. Fusarium sp. growth on SDA medium with different concentrations of Fermented Bamboo Shoot Acetone Extract using Food Poisoned Technique. (A) $10 \mathrm{mg} / \mathrm{ml}$ (B) $20 \mathrm{mg} / \mathrm{ml}$ (C) $30 \mathrm{mg} / \mathrm{ml}$ (D) $40 \mathrm{mg} / \mathrm{ml}$ (E) $50 \mathrm{mg} / \mathrm{ml}$ (F) Control (without extract). 


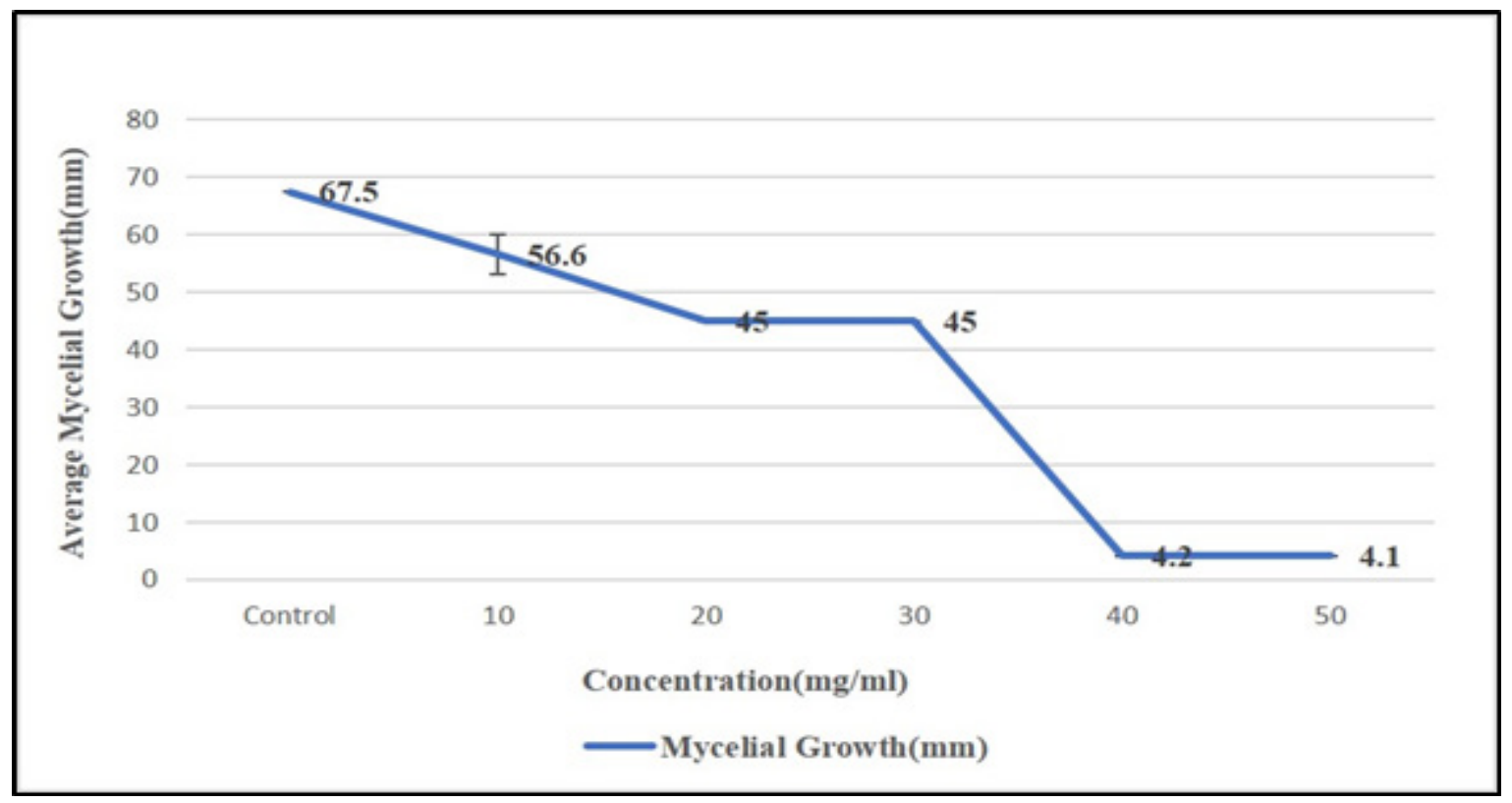

Fig 8. Average mycelial growth of Fusarium sp. in Acetone Extract of Fermented Bamboo Shoot Dendrocalamus hamiltonii

At the least concentration of $10 \mathrm{mg} / \mathrm{ml}$, all the test organisms are sensitive towards the extract. Among all, Staphylococcus aureus is most sensitive with highest inhibition zones of $14 \pm 1.73 \mathrm{~mm}$. The zone, however, decreases from E. coli with $13 \pm 0 \mathrm{~mm}$ to Pseudomonas aeruginosa with $11.6 \pm 0.57 \mathrm{~mm}$ at the same concentration. Gentamycin (Positive Control) showed $36.7 \mathrm{~mm}, 33.3 \mathrm{~mm}$ and $40 \mathrm{~mm}$ zones of inhibition against Staphylococcus aureus, Pseudomonas aeruginosa and Escherichia coli respectively.
This indicates the effectiveness of the acetone extract of fermented bamboo shoot against all the test organisms at the least concentration taken.

\section{Methanol Extract}

In case of methanol extract, Pseudomonas aeruginosa show zone of inhibition $10.6 \pm 1.15 \mathrm{~mm}$ at 10 $\mathrm{mg} / \mathrm{ml}$ concentration. However, Staphylococcus aureus and Escherichia coli do not show inhibition zones at 10 $\mathrm{mg} / \mathrm{ml}$. Staphylococcus aureus and Escherichia coli

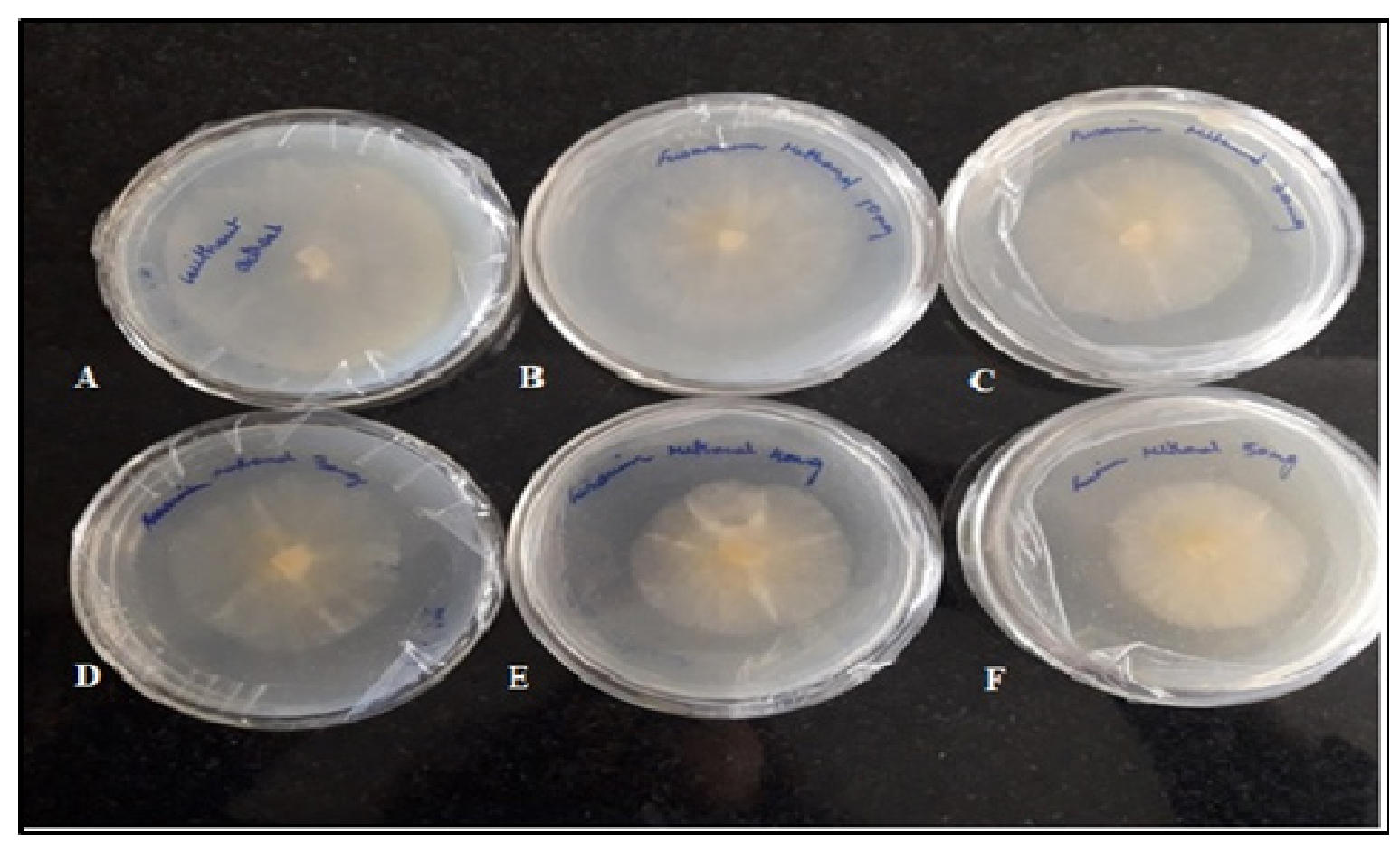

Fig. 9. Fusarium sp. growth on SDA medium with different concentrations of Fermented Bamboo Shoot Methanol Extract using Food Poisoned Technique. (A) Control (without extract) (B) 10 mg/ml (C) $20 \mathrm{mg} / \mathrm{ml}$ (D) $30 \mathrm{mg} / \mathrm{ml}$ (E) 40 $\mathrm{mg} / \mathrm{ml}(\mathrm{F}) 50 \mathrm{mg} / \mathrm{ml}$. 
showed inhibition zones at $20 \mathrm{mg} / \mathrm{ml}$ with $10 \pm 0 \mathrm{~mm}$ and $13.6 \pm 1.15$ respectively. Gentamycin (Positive Control) showed $36 \mathrm{~mm}, 33.3 \mathrm{~mm}$ and $40 \mathrm{~mm}$ inhibition zones against Staphylococcus aureus, Pseudomonas aeruginosa and Escherichia coli respectively.

This indicates that among all the test organisms, only Pseudomonas aeruginosa is most sensitive towards the least concentration of methanol extract of fermented bamboo shoot.

\section{Antifungal Screening}

The antifungal effect of the fermented bamboo shoot (Dendrocalamus hamiltonii) against the fungus Fusarium sp. showed a gradual decrease in the mycelial growth with the increase in the concentration of both the acetone and methanol extracts. The antifungal activity of acetone extracts is shown in Table 5 and Fig. 7, Fig. 8 and methanol extracts is shown in Table 6 and Fig. 9, Fig 10.

\section{Acetone Extract}

After incubation at room temperature for 5 days, it is observed that the increase in the concentration of extracts from $10 \mathrm{mg} / \mathrm{ml}$ to $50 \mathrm{mg} / \mathrm{ml}$, the mycelia growth gradually decreases from $56.6 \pm 3.5 \mathrm{~mm}$ to $41.0 \pm 0 \mathrm{~mm}$. The average mycelial growth of the control (without extract) is found to be $67.5 \mathrm{~mm}$. At $10 \mathrm{mg} / \mathrm{ml}$ (least) concentration of acetone extract, the mycelial growth is $56.6 \pm 3.5 \mathrm{~mm}$ which decreases as compared to that of the control. This shows the effect of the extract on the fungus Fusarium sp.

\section{Methanol Extract}

Similarly, the methanol extracts of fermented bamboo shoot show gradual decrease of mycelia growth from $55.6 \pm 1.4 \mathrm{~mm}$ to $45.0 \pm 0 \mathrm{~mm}$ with increase in the concentration of extracts from $10 \mathrm{mg} / \mathrm{ml}$ to $50 \mathrm{mg} / \mathrm{ml}$. Compared to the control (without extract) having mycelial growth of $67.5 \mathrm{~mm}$, the mycelial growth decreases at the least concentration of extract at $10 \mathrm{mg} / \mathrm{ml}$ with $55.6 \pm 1.4$ $\mathrm{mm}$. This indicates the antagonistic effect of the extract against Fusarium sp.

\section{Hydrogen Peroxide Scavenging Activity}

In this study, Hydrogen Peroxide Scavenging Activity Method is adopted where hydrogen peroxide acts as free radicals against the antioxidant substances present in the extract. The absorbance is measured spectrophotometrically at $230 \mathrm{~nm}$.

The scavenging activity of acetone and methanol extracts are shown in Table 7 and Fig. 11, $10 \mathrm{mg} / \mathrm{ml}$ and $20 \mathrm{mg} / \mathrm{ml}$ concentrations of methanol extract are found to have a scavenging activity of $17.31 \%$ and $35.77 \%$ hydrogen peroxide respectively. However, $10 \mathrm{mg} / \mathrm{ml}$ concentration of acetone extract does not show any scavenging activity while $20 \mathrm{mg} / \mathrm{ml}$ scavenged $50.70 \%$ of hydrogen peroxide. Ascorbic acid (Standard) exhibited $7.69 \%$ and $25.71 \%$ of scavenging activity of hydrogen peroxide at $10 \mathrm{mg} / \mathrm{ml}$ and $20 \mathrm{mg} / \mathrm{ml}$ respectively.
Table 6. Antifungal activity of the Methanol Extract of Fermented Bamboo Shoot on Fusarium sp.

\begin{tabular}{|c|c|}
\hline $\begin{array}{c}\text { Concentration } \\
\text { of Methanol } \\
\text { Extract }(\mathrm{mg} / \mathrm{ml})\end{array}$ & $\begin{array}{c}\text { Average mycelial } \\
\text { growth }(\mathrm{mm})\end{array}$ \\
\hline 10 & $55.6 \pm 1.4$ \\
\hline 20 & $53.3 \pm 3.5$ \\
\hline 30 & $52.3 \pm 0.7$ \\
\hline 40 & $50.0 \pm 0$ \\
\hline 50 & $45.0 \pm 0$ \\
\hline Control & 67.5 \\
\hline
\end{tabular}

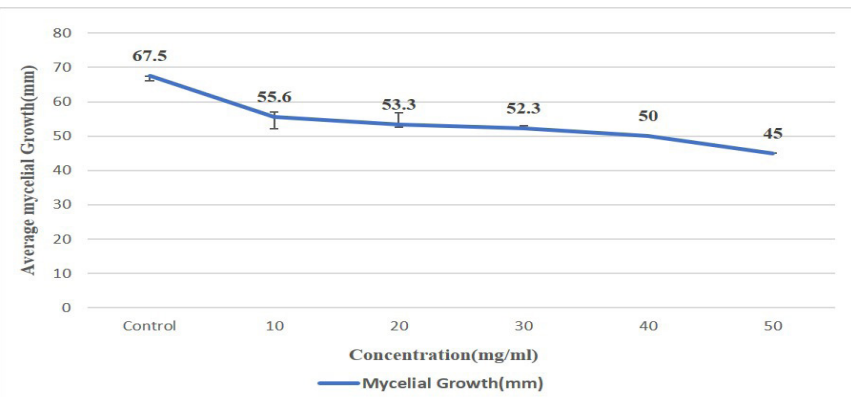

Fig. 10. Average mycelial growth of Fusarium sp. in Methanol Extract of Fermented Bamboo Shoot Dendrocalamus hamiltonii

Table 7. Hydrogen Peroxide Scavenging Activity of Fermented Bamboo Shoot Dendrocalamus hamiltonii

\begin{tabular}{|c|c|c|c|c|c|}
\hline \multicolumn{2}{|c|}{} & $\begin{array}{r}\text { Concentration } \\
(\mathrm{mg} / \mathrm{ml})\end{array}$ & $\begin{array}{c}\text { Absorbance } \\
\text { of Control }\end{array}$ & $\begin{array}{c}\text { Absorbance } \\
\text { of Test }\end{array}$ & $\begin{array}{c}\text { \% Scavenging } \\
\text { activity }\end{array}$ \\
\hline Standard & $\begin{array}{c}\text { Ascorbic } \\
\text { acid }\end{array}$ & 10 & 0.026 & 0.024 & 7.69 \\
\cline { 3 - 6 } & $\begin{array}{c}\text { Methanol } \\
\text { Sample }\end{array}$ & 10 & 0.104 & 0.086 & 17.31 \\
\hline
\end{tabular}

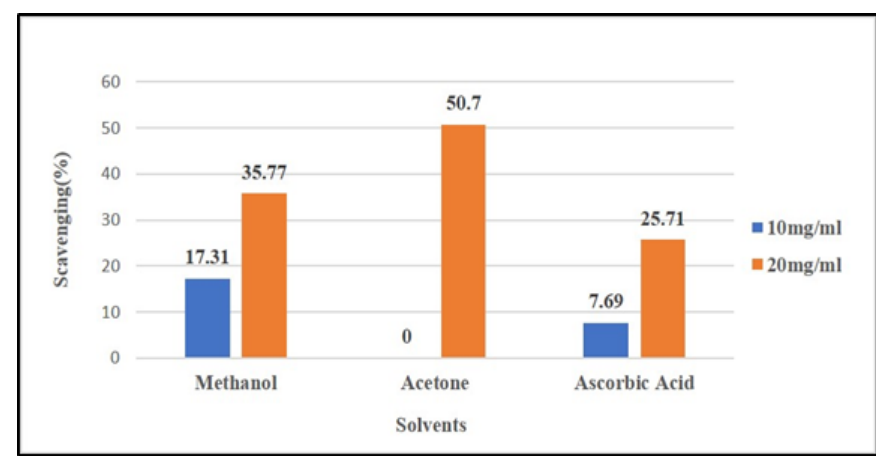

Fig. 11. Percentage of Hydrogen Peroxide Scavenging Activity of Fermented Bamboo Shoot Dendrocalamus hamiltonii Table 8. Percentage of antifungal activity of the fermented bamboo shoot extracts on Fusarium sp.

\begin{tabular}{|c|c|c|}
\hline Solvents & $\begin{array}{c}\text { Average Mycelial } \\
\text { growth }\end{array}$ & $\begin{array}{c}\text { Antifungal } \\
\text { Activity (\%) }\end{array}$ \\
\hline Acetone & 45.92 & 31.97 \\
\hline Methanol & 51.24 & 24.08 \\
\hline
\end{tabular}


The above results indicate the presence of potential substances such as phenolics and flavonoids that have redox properties that allow them to serve as antioxidants in both acetone and methanol extracts.

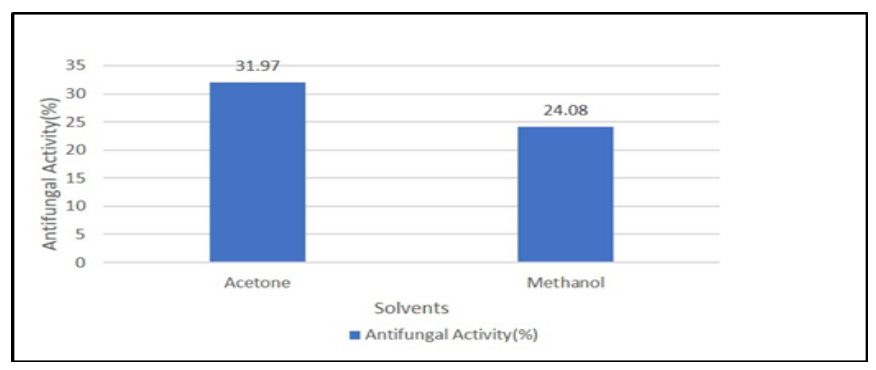

Fig. 12. Antifungal Activity of Acetone and Methanol Extract of fermented shoot of Dendrocalamus hamiltonii

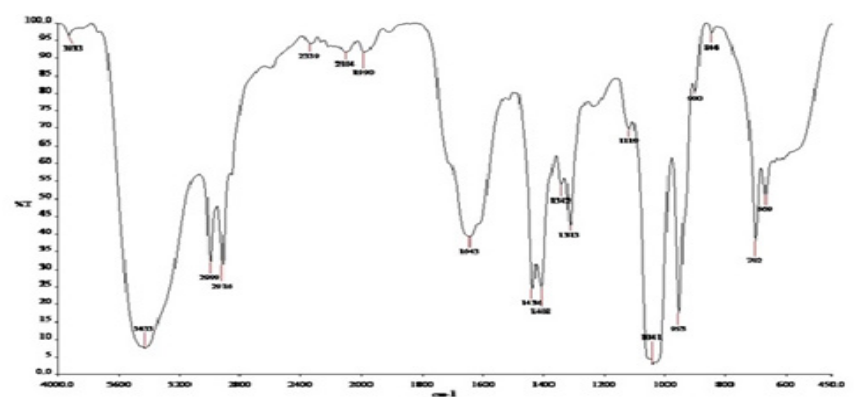

Fig. 13. FT-IR Spectrum of Methanol Extracts of Fermented Bamboo Shoot Dendrocalamus hamiltonii

\section{Percentage of Antifungal Activity}

The antifungal activity (\%) was calculated against the control (without extract) having an average mycelia growth of $67.5 \mathrm{~mm}$. It was found that acetone extract has more antifungal activity with $31.97 \%$ as compared to that of methanol extract with antifungal activity of $24.08 \%$ as shown in Table 8 and Fig. 12. The results showed that the acetone extracts may contain more phytochemicals having antifungal properties than methanol extracts.

\section{FTIR Analysis}

The FT-IR analysis of methanol extract (Fig 13), alcohols are represented at the peak value of 3433 $\mathrm{cm}^{-1}$ and $1119 \mathrm{~cm}^{-1}$, which corresponds to $\mathrm{O}-\mathrm{H}$ and $\mathrm{C}-\mathrm{H}$ stretc hing respectively. Alkanes correspond to the peak value $2999 \mathrm{~cm}^{-1}$ and $1408 \mathrm{~cm}^{-1}$, with the respective peak assignment $\mathrm{C}-\mathrm{H}$ stretching and $-\mathrm{C}-\mathrm{H}$ - bending. Acids are assigned to the peak value $2999 \mathrm{~cm}^{-1}$ and $1313 \mathrm{~cm}^{-1}$ with the respective peak assignment $\mathrm{O}-\mathrm{H}$ stretching and $\mathrm{C}-\mathrm{O}$ stretching. Alkynes are corresponded to the peak value $2104 \mathrm{~cm}^{-1}$ showing $-\mathrm{C}=\mathrm{C}$ - stretching, alkenes, however, are represented at $1643 \mathrm{~cm}^{-1}$

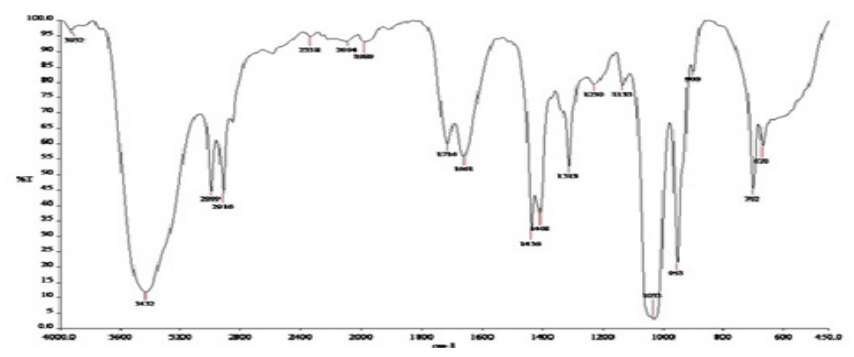

,Fig. 14. FT-IR Spectrum of Acetone Extracts of Fermented Bamboo Shoot Dendrocalamus hamiltonii

$900 \mathrm{~cm}^{-1}, 844 \mathrm{~cm}^{-1}$ peak values showing $\mathrm{C}=\mathrm{C}$ stretching for the first peak value and $=\mathrm{C}-\mathrm{H}$ bending for the second and third values. $=\mathrm{C}-\mathrm{H}$ bending also corresponds to alkene at $669 \mathrm{~cm}^{-1}$. Amides and Amines show peak value at $1643 \mathrm{~cm}^{-1}$ and $1119 \mathrm{~cm}^{-1}$ respectively with the respective peak assignments $\mathrm{C}=\mathrm{O}$ stretching and $\mathrm{C}-\mathrm{N}$ stretching. Amines also show a peak value at 1313 $\mathrm{cm}^{-1}$ with $\mathrm{C}-\mathrm{N}$ stretching. Alkyl halides show peak value at $1342 \mathrm{~cm}^{-1}, 1119 \mathrm{~cm}^{-1}, 1041 \mathrm{~cm}^{-1}$ and $669 \mathrm{~cm}^{-1}$ with C-F stretching for the first, second and third values and $\mathrm{C}-\mathrm{Cl}$ stretching for the fourth value. Ether and esters are represented by the peak value $1119 \mathrm{~cm}^{-1}$ and 1041 with

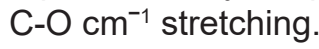

The FT-IR analysis of acetone extracts (Fig 14), alkanes have peak value at $2999 \mathrm{~cm}^{-1}, 2916 \mathrm{~cm}^{-1}$ with $\mathrm{C}-\mathrm{H}$ stretching and $1436 \mathrm{~cm}^{-1}$ and $1408 \mathrm{~cm}^{-1}$ with $-\mathrm{C}-$ $\mathrm{H}$ - bending. Alkenes have $=\mathrm{C}-\mathrm{H}$ bending at $953 \mathrm{~cm}^{-1}$ and $702 \mathrm{~cm}^{-1}$ peak values. Alcohols correspond to $\mathrm{C}-\mathrm{O}$ stretching at $1133 \mathrm{~cm}^{-1}$ and $1033 \mathrm{~cm}^{-1}$ peak values, however, alkyl halides show $\mathrm{C}-\mathrm{F}$ stretching at peak value $1133 \mathrm{~cm}^{-1}, 1033 \mathrm{~cm}^{-1}$ and $\mathrm{C}-\mathrm{Cl}$ stretching at $702 \mathrm{~cm}^{-1}$ and $670 \mathrm{~cm}^{-1}$. Amines correspond to $3432 \mathrm{~cm}^{-1}$ peak value with $\mathrm{N}-\mathrm{H}$ stretching, $1313 \mathrm{~cm}^{-1}$ with $\mathrm{C}-\mathrm{N}$ stretching and $1230 \mathrm{~cm}^{-1}$ with $\mathrm{C}-\mathrm{N}$ bending. Amides showed peak value at $1661 \mathrm{~cm}^{-1}$ with peak assignments $\mathrm{C}=\mathrm{O}$ stretching and $\mathrm{N}-\mathrm{H}$ bending, whereas, ketones show $\mathrm{C}=\mathrm{O}$ stretching at 1716 peak value. Aromatic compounds show peak value at $1436 \mathrm{~cm}^{-1}$ and $1408 \mathrm{~cm}^{-1}$ with $\mathrm{C}=\mathrm{C}$ stretching as peak assignment.

\section{Conclusion}

Bamboo belonging to Poaceae family has immense potential as medicinal plant. Dendrocalamus hamiltonii is one of the bamboo species which is widely available in Meghalaya. The study of antioxidants and antimicrobial properties of fermented $D$. hamiltonii shoots is initiated by extracting the phytochemicals present in the bamboo shoot using Soxhlet extracting procedures. Two solvents were used for the extraction. They are acetone and methanol where their extraction yield is found to be $25.78 \%$ and $31.08 \%$ respectively. The presence of phytochemicals extracted is identified using different qualitative test and FT-IR analysis. The Scavenging of free radicals by the extracts of fermented bamboo shoot is carried out by Hydrogen Peroxide Scavenging activity using ascorbic acid as standard. The methanol extract showed $17.31 \%$ of scavenging activity at $10 \mathrm{mg} /$ $\mathrm{ml}$ whereas the same concentration, the acetone extract does not scavenge any free radicals. This indicates the presence of antioxidant substances in the fermented bamboo shoot.

Antimicrobial screening is done by using four test organisms namely Staphylococcus aureus, Escherichia coli, Pseudomonas aeruginosa and Fusarium sp. Agar 
well diffusion technique and food poisoned technique are the methods adopted to determine the antibacterial and antifungal respectively. In agar well diffusion method, the zone of inhibition increases with the increase of concentration from $10 \mathrm{mg} / \mathrm{ml}-50 \mathrm{mg} / \mathrm{ml}$. Taking the least concentration that is $10 \mathrm{mg} / \mathrm{ml}$ the zone of inhibition of acetone extract for Staphylococcus aureus, Escherichia coli and Pseudomonas aeruginosa are $14 \pm 1.73 \mathrm{~mm}$, $13 \pm 0$ and $11.6 \pm 0.57$. Methanol extract showed zone of inhibition only for Pseudomonas aeruginosa with $10.6 \pm 1.15 \mathrm{~mm}$ at $10 \mathrm{mg} / \mathrm{ml}$. Staphylococcus aureus and Escherichia coli however, are not inhibited by the methanol extract at $10 \mathrm{mg} / \mathrm{ml}$.

The mycelial growth of Fusarium sp. decreases with an increase in the concentration of the extracts. At $10 \mathrm{mg} / \mathrm{ml}$ (least) concentration of acetone and methanol extracts the mycelial growth are found to be $56.6 \pm 3.5$ $\mathrm{mm}$ and $55.6 \pm 1.4$ which decreases as compared to that of the control (without extract) having mycelial growth of $67.5 \mathrm{~mm}$. In the study, the methanol and acetone extract of the fermented bamboo shoot showed that they have antimicrobial activity against the test organisms. They also show antioxidant activity. This indicates that the fermented bamboo shoots may serve as a source or substitution for synthetic drugs in pharmaceuticals. The used of fermented bamboo shoots which is a natural source is more significant than synthetic drugs as they induce less side effects.

\section{Acknowledgments}

The authors are thankful to the Department of Life Sciences, Kristu Jayanti College, for giving an opportunity to undertake this project work and supporting us immensely throughout the duration by providing all the necessary facilities to carry out this project work. Also we thank CSIR-CECRI, Karaikudi for the FTIR analysis.

\section{References}

1. Singh, S.A., Bora, T.C. and Singh, N.R. (2012) Preliminary phytochemical analysis and antimicrobial potential of fermented Bambusa balcooa shoots. The Bioscan, 7(3), 391-394.

2. Singh, S.A., Singh, H.D., Nongmaithem, R., Bora, T.C. and Singh, N.R. (2011). Comparative study of chemical properties of Soibum-A traditional fermented bamboo shoot product and its biological investigation. Int. J. Biosci., Biochem and Bioinfo, 1(2), 114-118.

3. Bisht, M.S., Nirmala, C. and Meetei, O.S., (2015). Bamboo shoots for food in North-East India: conventional and contemporary. In Proceedings of 10th world bamboo congress, theme: food and pharmaceuticals.

4. Choudhury, D., Sahu, J.K. and Sharma, G.D. (2012).
Bamboo shoot: Microbiology, Biochemistry and Technology of fermentation-a review.

5. Thakur, K., Rajani, C.S., Tomar, S.K. and Panmei, A. (2016). Fermented bamboo shoots: A riche niche for beneficial microbes. J Bacteriol Mycol Open Access, 2(4), p.00030.

6. Doughari, J.H (2012). Phytochemicals: extraction methods, basic structures and mode of action as potential chemotherapeutic agents. In Phytochemicals-A global perspective of their role in nutrition and health. InTechOpen.

7. Bag, G.C., Devi, P.G. and Bhaigyabati, T.H (2015). Assessment of total flavonoid content and antioxidant activity of methanolic rhizome extract of three Hedychium species of Manipur valley. International Journal of Pharmaceutical Sciences Review and Research, 30(1), 154-159.

8. Formagio, A., Volobuff, C., Santiago, M., Cardoso, C., Vieira, M. and Valdevina Pereira, Z. Evaluation of antioxidant activity, total flavonoids, tannins and phenolic compounds in Psychotria leaf extracts. Antioxidants, 3(4), 745-757 (2014).

9. Wafa, N., Sofiane, G. and Mouhamed, K. (2016). The antioxidant and antimicrobial activities of flavonoids and tannins extracted from Phlomis bovei De Noé. Eur. J. Exp. Biol, 6(3), 55-61.

10. Kapruvan S, Bakshi M, Kaur M. (2014). Effect of growth regulators on the in vitro multiplication of Dendrocalamus hamiltonii. Journal of Engineering Research and Application, 4, 83-86.

11. Sood S, Wallia S, Gupta M, Sood A, (2013). Nutritional characterisation of shoots and the Edible Products of an Edible Bamboo- Dendrocalamus hamiltonii. Curr res lutr food sci 1 (2).

12. Nagaraj H, Kanchan R, Lalchandami R., Vanlalrhuaii H. (2017). Fungal Degradation Studies on Bambusa tulda and Dendrocalamus hamiltonii at varying maturity. International Journal of Agriculture Sciences, 9, 4566-4568.

13. Chavhan, D.M., Hazarika, M., Brahma, M.L., Hazarika, R.A. and Rahman, Z. (2015). Effect of incorporation of fermented bamboo shoot on physicochemical and microbial quality of pork pickle. Journal of food science and technology, 52(2), 12231227.

14. Das, A., Nath, D.R., Kumari, S. and Saha, R. (2013). Effect of fermented bamboo shoot on the quality and shelf life of nuggets prepared from desi spent hen. 
Veterinary World, 6(7).

15. Tiwari, P., Kumar, B., Kaur, M., Kaur, G. and Kaur, H. (2011). Phytochemical screening and extraction: a review. Internationale pharmaceutica sciencia, 1(1), 98-106.

16. Dhawan, D. and Gupta, J. (2017). Research Article Comparison of Different Solvents for Phytochemical Extraction Potential from Datura metel Plant Leaves. Int. J. Biol. Chem, 11, 17-22.
17. Serhat K, Sait C, Semra T, Okkes T and Ismail T. (2012). Hydrogen Peroxide Radical Scavenging and Total Antioxidant Activity of Hawthorn. Chemistry Journal, 02, 9-12.

18. Balouiri, M., Sadiki, M. and Ibnsouda, S.K. (2016). Methods for in vitro evaluating antimicrobialactivity: A review. Journal of pharmaceutical analysis, 6(2), 71- 